Обзор / Review

https://doi.org/10.18619/2072-9146-2020-2-16-22 УДК 635.1:639.3(470)

Ветрова С.А, Вюртц Т.С., Заячковская Т.В., Степанов В.А.

Федеральное государственное бюджетное научное учреждение

"Федеральный научный центр овощеводства" (ФГБНУ ФНЦО)

143072, Россия, Московская область, Одинцовский район, п. ВНИИССОК,

ул. Селекционная, д.14

E-mail: lana-k2201@mail.ru

Конфликт интересов: Авторы заявляют об отсутствии конфликта интересов.

Для цитирования: Ветрова С.А, Вюртц Т.С., Заячковская Т.В., Степанов В.А. Современное состояние рынка овощных корнеплодов в РФ и пути решения проблемы продовольственной безопасности. Овощи России. 2020;(2):16-22. https://doi.org/10.18619/2072-9146-2020-2-16-22

Поступила в редакцию: 26.03.2020

Принята к печати: 09.04.2020

Опубликована: 25.04.2020

Svetlana A. Vetrova, Tatyana S. Vjurtts, Tatyana V. Zayachkovskaya, Victor A. Stepanov

Federal State Budgetary Scientific Institution Federal Scientific Vegetable Center (FSBSI FSVC) 14, Selectsionnaya str., VNIISSOK, Odintsovo district, Moscow region, Russia, 143072 E-mail: lana-k2201@mail.ru

Conflict of interest: The authors declare no conflict of interest.

For citation: Vetrova S.A., Vjurtts T.S.,

Zayachkovskaya T.V., Stepanov V.A. Current state of the vegetable root crop market in the Russian Federation and ways to solve the problem of food security. Vegetable crops of Russia. 2020;(2):16-22. (In Russ.) https://doi.org/10.18619/2072-91462020-2-16-22

Received: 26.03.2020

Accepted for publication: 09.04.2020

Accepted: 25.04 .2020

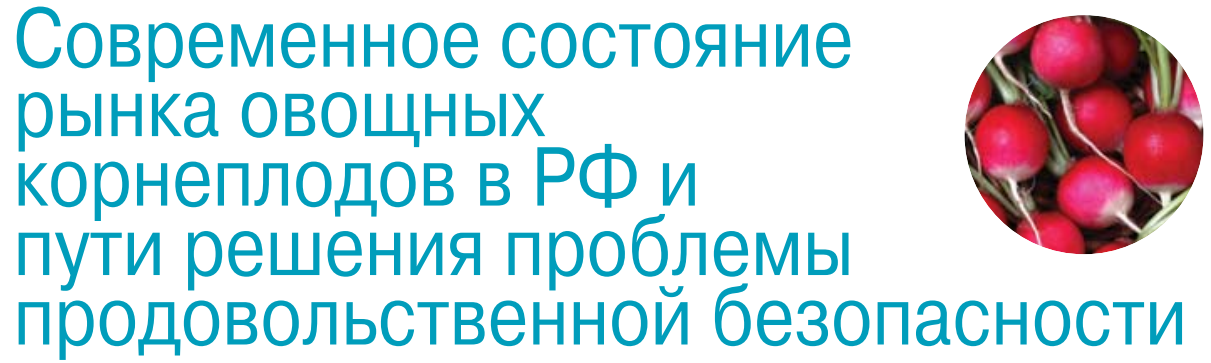

PE3ЮME

Актуальность, методы. Среди овощных культур особую популярность у населения как в РФ, так и за рубежом, имеют столовые корнеплоды: морковь, свекла столовая, редис, репа и пастернак, которые являются источниками разнообразных витаминов и БАВ. Значительную долю в структуре производства и посевных площадей занимают морковь и свекла столовая. Согласно данным FAOSTAT в 2018 году в РФ произведено 1508 тыс. т моркови и 837 тыс. т свеклы столовой, что составляет $60 \%$ и $30 \%$ соответственно от существующих потребностей, даже импорт этой продукции не позволяет полностью их удовлетворить. Исходя из стратегии продовольственной безопасности для повышения обеспеченности населения отечественной продукцией необходимо не только увеличение посевных площадей, но и быстрое внедрение сортов и гибридов $F_{1}$ отечественной селекции, отвечающих требованиям промышленных технологий.

Результаты. С учетом этих требований селекционерами ФГБНУ ФНЦО, с использованием классических и современных методов, способствующих ускорению селекционного процесса, созданы сорта и гибриды столовых корнеплодов. Морковь столовая: F1 Надежда (сортотип Нантская), F1 Риф (сортотип Шантенэ) с урожайностью более 90 т/га, высокой выровненностью, сохранностью 95-98\%, групповой устойчивостью к болезням хранения, сорт Маргоша (сортотип Нантская / Берликум) со стабильной урожайностью до 90 т/га, высокой экологической пластичностью. Одно-двусемянные сорта свеклы столовой: Бордо односемянная, Любава, Гаспадыня, с уровнем товарности 95-98\%, с интенсивно окрашенной мякотью без четко выраженных колец. Репа японская Гейша и Снегурочка со съедобными листьями и сочной нежной мякотью корнеплода и ультраскороспелые формы Сапфир, Бирюза и Селекта для проточной гидропоники; скороспелые сорта редиса Ария, Соната, Миф и Мавр, устойчивые к стеблеванию и высоким содержанием аскорбиновой кислоты.

Ключевые слова: продовольственная безопасность, импортозамещение, товарная продукция, столовые корнеплоды, направления селекции, сорт, гибрид.

\section{Current state of the vegetable root crop market in the Russian Federation and ways to solve the problem of food security}

\section{ABSTRACT}

Relevance and methods. Among vegetable crops, root crops are particularly popular among the population both in the Russian Federation and abroad: carrots, beetroot, radish, turnips and parsnips, which are sources of various vitamins. A significant share in the structure of production and acreage is occupied by carrot and beetroot. According to FAOSTAT data, in 2018, the Russian Federation produced 1508 thousand tons of carrot and 837 thousand tons of beetroot, which is 60 and $30 \%$, respectively, of the existing needs, even the import of these products does not fully meet them. Based on the strategy of food security, in order to increase the population's supply with domestic products, it is necessary not only to increase the acreage, but also to quickly introduce $F_{1}$ varieties and hybrids of domestic selection that meet the requirements of industrial technologies.

Results. Given these requirements, breeders, FSBSI Federal Scientific Vegetable Center, using classical and modern methods to accelerate the breeding process, developed varieties and hybrids table root crops. Carrot $F_{1}$ Nadezda (variety Nantes), $F_{1}$ Rif (variety Shantane) with a yield of more than $90 \mathrm{t} / \mathrm{ha}$, high uniformity, safety $95-$ $98 \%$, group resistance to diseases storage, Margosha variety (variety Nantes/Berlicum) with a stable yield at least $100 \mathrm{t} / \mathrm{ha}$, high environmental resistance; single- and double-seeded varieties of beets, Bordo odnosemyannaya, Lubava, Gaspadynya, with a marketability level of $95-98 \%$, intensely colored pulp without clearly defined rings; Japanese Geisha and snow maiden turnips with edible leaves and juicy tender root pulp and ultra-ripe forms of Sapfir, Biryuza and Selecta for flow hydroponics; precocious varieties of radish Aria, Sonata, myth and moor resistant to stalk and high ascorbic acid content.

Keywords: provision food, import substitution, marketable product, root crops, the direction selection, hybrid, variety. 
B! настоящее время в связи со сложившейся политической ситуацией и введением санкций, все большее внимание уделяется продовольственной безопасности РФ, которая предусматривает продовольственную независимость, как определенный уровень самообеспечения сельскохозяйственной продукцией, сырьем и продовольствием, в том числе овощами и бахчевыми не менее 90\%; семенами основных сельскохозяйственных культур отечественной селекции - не менее 75\% [4].

Среди существующего разнообразия овощей, большую популярность как в РФ, так и за рубежом, имеют столовые корнеплоды: морковь, свекла, редис, редька, репа, пастернак. Эти культуры являются источниками разнообразных природных витаминов, и ввиду невысоких цен, как на товарную продукцию, так и на семена, являются общедоступными и возделываются издавна и повсеместно в нашей стране [13]. В крупнотоварном овощеводстве РФ представлены две основные культуры: морковь и свекла столовая. В отдельных регионах и хозяйствах есть опыт возделывания редиса, его перевода из мелкотоварной в крупнотоварную культуру. На сегодняшний день под товарным редисом занято более 4000 га, из них около 400 га в защищенном грунте [9]. Все остальные корнеплодные культуры малораспространенные и выращиваются мелкотоварными производителями или в личных подсобных хозяйствах.

В соответствии с приказом Министерства здравоохранения РФ №614 от 19 августа 2016 года «Об установлении рекомендаций по рациональным нормам потребления пищевой продукции, отвечающим требованиям здорового питания» норма потребления на человека в год моркови столовой составляет 17 кг, свеклы столовой - 18 кг. Исходя из этих нормативов и численности населения, потребность РФ в товарной продукции корнеплодных культур приблизительно составляет по моркови 2,5 млн т, по свекле - 2,6 млн т.

\section{Фактическое производство и}

уровень обеспеченности товарной продукцией

В мировом объеме товарного производства корнеплодных культур (по данным FAOSTAT) в течение последних пяти лет Российская Федерация стабильно занимает второе место, существенно уступая Китайской Народной Республике, как по валовым сборам, так и по посевным площадям (рис.1) [18]. В 2018 году в РФ было произведено моркови 1508 тыс. т, свеклы - 837 тыс. т, что составляет $60 \%$ и $32 \%$ от существующей потребности в целом по стране. Уровень обеспеченности населения морковью столовой по округам в 2018 году варьировал от 29\% до 112\%; свеклой столовой - в пределах 19-43\%. Наиболее полно потребность населения по этим культурам, за счет продукции местного производства, удовлетворена в Южном федеральном округе. Наименьшая обеспеченность отмечена в Дальневосточном федеральном округе, поскольку, не смотря на внушительные посевные площади под этими культурами ввиду климатических особенностей региона и других факторов, урожайность в среднем составляла 16-18 т/га $[10,12]$. Учитывая то, что большая часть полученной продукции (около 60\%) приходится на личные подсобные хозяйства населения, которые выращивают овощи для собственного потребления и составляют лишь $25 \%$ населения нашей страны, уровень обеспеченности городского населения корнеплодами напрямую зависит от развития промышленного сектора овощеводства.

Основное промышленное производство корнеплодных культур сосредоточено в Центральном, Южном и

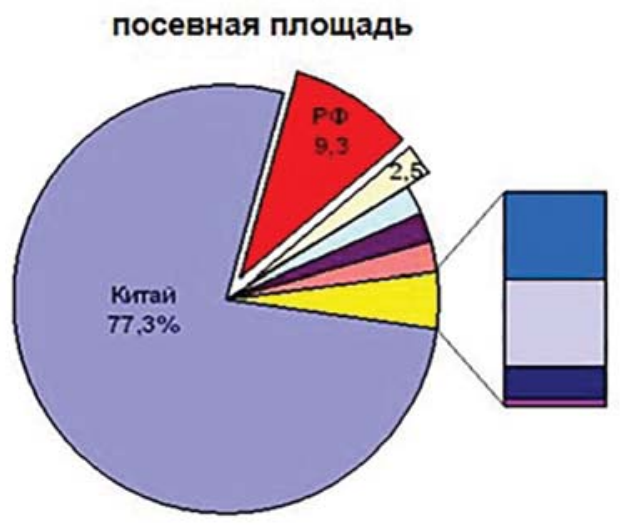

\section{8}

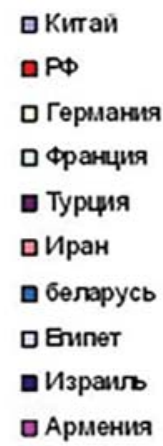

валовый сбор

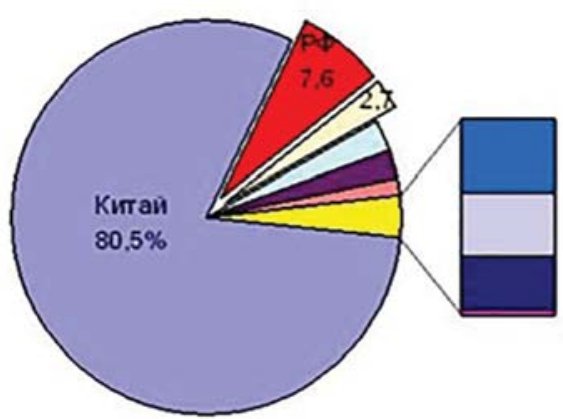

Рис. 1. Товарное производство столовых корнеплодов (морковь столовая и турнепс, другие корнеплоды и клубнеплоды) в мире (по данным FAOSTAT)

Fig. 1. Commercial production of table root crops (carrots and turnips, other root crops and tubers) in the world (FAOSTAT)

Таблица 1. Основные регионы РФ промышленного выращивания моркови и свеклы столовой (2018 год) Table 1. Main regions of the Russian Federation for industrial carrot and beetroot (2018)

\begin{tabular}{|c|c|c|c|c|c|}
\hline \multicolumn{3}{|c|}{ Морковь } & \multicolumn{3}{|c|}{ Свекла } \\
\hline $\begin{array}{c}\text { Регион } \\
\text { выращивания }\end{array}$ & $\begin{array}{c}\text { Площадь } \\
\text { посева, } \\
\text { тыс. га (\%) }\end{array}$ & $\begin{array}{c}\text { Валовой } \\
\text { сбор, } \\
\text { тыс. т (\%) }\end{array}$ & $\begin{array}{c}\text { Регион } \\
\text { выращивания }\end{array}$ & $\begin{array}{c}\text { Площадь } \\
\text { посева, } \\
\text { тыс. га (\%) }\end{array}$ & $\begin{array}{c}\text { Валовой } \\
\text { сбор, } \\
\text { тыс. т (\%) }\end{array}$ \\
\hline Волгоградская область & $3,68(15,9)$ & $187,4(23,1)$ & Московская область & $1,54(8,7)$ & $61,2(14,3)$ \\
\hline Московская область & $1,9(8,2)$ & $99,2(12,2)$ & Республика Татарстан & $0,88(4,9)$ & $17,1(4,0)$ \\
\hline Краснодарский край & $1,35(5,8)$ & $26,4(3,3)$ & Самарская область & $0,84(4,7)$ & $33,2(7,8)$ \\
\hline Новгородская область & $0,9(3,9)$ & $32,8(4,0)$ & Краснодарский край & $0,81(4,6)$ & $18,4(4,3)$ \\
\hline Самарская область & $0,85(3,7)$ & $37,9(4,7)$ & Ленинградская область & $0,74(4,2)$ & $21,4(5,0)$ \\
\hline Другие & $14,5(62,5)$ & $426,5(52,6)$ & Другие & $12,9(72,5)$ & $275,3(64,5)$ \\
\hline Всего & $23,2(100)$ & $810,0(100)$ & Всего & $17,8(100)$ & $427,0(100)$ \\
\hline
\end{tabular}


Приволжском федеральных округах, в которых выращивается около 70\% валового сбора. Лидерами по объему производства моркови в 2018 году стали Волгоградская, Московская, Новгородская, Самарская области и Краснодарский край. Суммарная доля производства в этих регионах составила около 50 \% от общего валового сбора. Наибольшие объемы производства свеклы столовой получены в Московской, Самарской, Ленинградской областях, республике Татарстан, Краснодарском крае (табл. 1).

В целом по стране в промышленном секторе овощеводства (сельхозорганизации и фермерские хозяйства, без учета хозяйств населения) по моркови столовой в 2018 году отмечено незначительное снижение посевных площадей (с 25,1 до 23,2 тыс. га) и валовых сборов (с 844 до 810 тыс. т) относительно предыдущего 2017 года. Однако следует отметить, что за последние годы за счет увеличения урожайности (с 24,8 т/га до 34,9 т/га), промышленное производство моркови выросло на 229 тыс. тонн или на 28,3\% (рис. 1) [19].

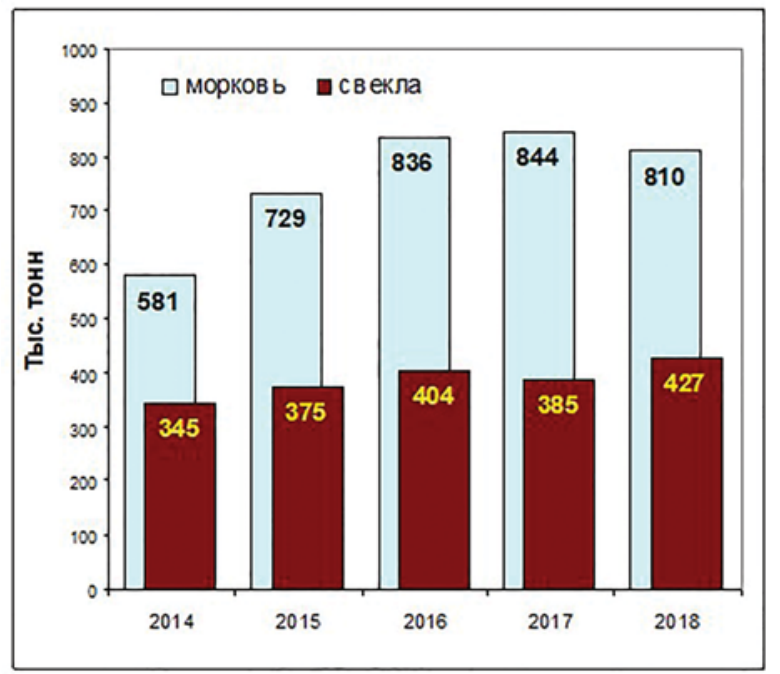

Рис.2. Валовые сборы моркови и свеклы столовой в России в промышленном секторе овощеводства (2014-2018)

Fig. 2. Gross collections of carrots and beetroot in Russia in the industrial sector of vegetable growing (2014-2018)

По свекле столовой валовые сборы в 2018 году превысили показатели 2017 года на 10,9\% и составляли 427,0 тыс. тонн (рис. 2). За последние годы наблюдается устойчивый рост производства свеклы столовой как за счет увеличения посевных площадей (на 2,2 тыс. га), так и за счет повышения урожайности (с 21,3 т/га до 24,0 т/га) [20].

Несмотря на увеличение объема валовых сборов этих культур, на сегодняшний день городское население не в полной мере обеспечено столовыми корнеплодами отечественного производства. Уровень обеспеченности по моркови столовой в 2018 году составил около 40\%, свеклы - около 19\%. В связи с этим население вынуждено покупать в сетевых магазинах продукцию импортирующих стран.

\section{Объемы импорта и экспорта}

По данным Федеральной таможенной службы [21], наибольшая доля импорта по группе корнеплодных культур приходится на товарную продукцию моркови столовой, значительная часть которой импортируется с марта по июль. Большие объемы импорта в этот период связаны как с недостатком продукции российского производства, так и с потерями части урожая во время длительного хранения. Не смотря на вводимые санкции и рост валовых сборов, в 2017 году произошло увеличение объемов импорта товарной продукции моркови столовой в Россию на $19,7 \%$.

В 2019 году отмечено незначительное снижение ввозимой продукции (до 3,5\%) относительно предшествующих двух лет (рис. 3). За последние годы бессменным лидером по ввозимой продукции является Израиль. В 2016 году на его долю приходилось более 50\% всего объема импорта товарной моркови. В 2019 году произошло увеличение доли продукции, поставляемой из Китая, Белоруссии и Египта. Также незначительная часть товарной продукции моркови импортируется из стран ближнего зарубежья: Киргизия, Казахстан, Узбекистан и др., на их долю в 2019 году приходилось около 6\% ввозимого объема (рис. 4).

Объемы ввозимой товарной продукции свеклы столовой в разы меньше, чем моркови. Не смотря на активную политику импортозамещения, до 2018 года отмечен рост объемов импорта свеклы столовой в РФ, и только в 2019 году произошло снижение ввозимой продукции на $28,4 \%$. Этому способствовало увеличение валовых сборов в 2018 году (рис. 3). В 2016 году товарная продукция свеклы примерно в равных долях ввозилась из стран ближнего и дальнего зарубежья. Лидирующие позиции среди них занимали Китай, Беларусь, Израиль и Казахстан. В 2019 году большая часть продукции (около $65 \%$ от общего объема) поставлялась из стран ближнего зарубежья и Китая (рис.4).

По репе и прочим столовым корнеплодам прослеживается тенденция снижения объемов импорта. Минимальные объемы ввозимой из-за рубежа продукции по этой группе культур отмечены в 2019 году.

Из представленных показателей следует, что даже с учетом импортной продукции, население нашей страны не в
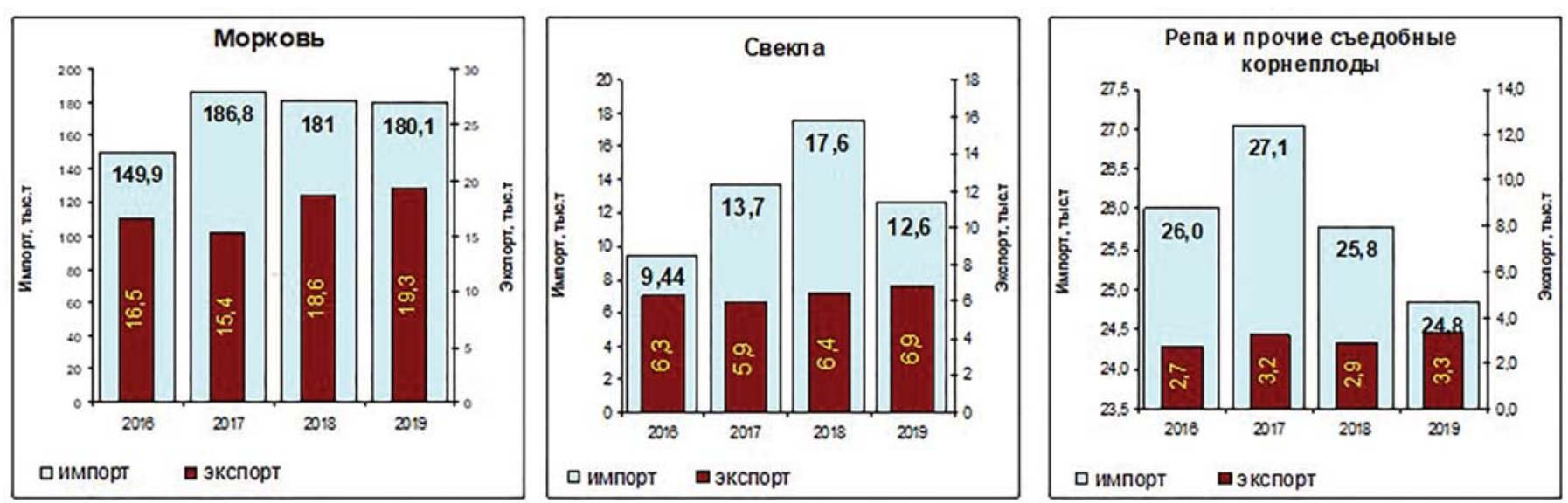

Рис. З. Импорт и экспорт товарной продукции группы столовых корнеплодов в РФ, 2016-2019гг. (тыс. тонн) Fig. 3. Import and export of commercial products of the table root crop group in the Russian Federation, 2016-2019 (thousand tons) 


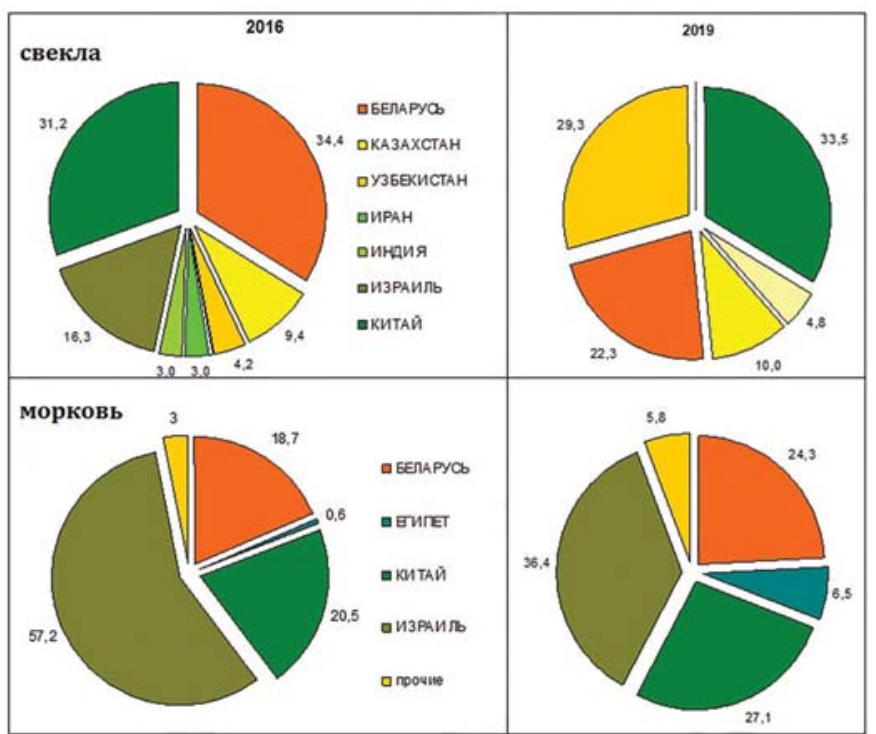

Рис. 4. Основные страны-импортеры товарной продукции моркови и свеклы столовой в РФ (2016, 2019гr.)

Fig. 4. Main countries-importers of commercial products of carrots and beets in the Russian Federation $(2016,2019)$ по увеличению валовых сборов ложится на сельхозорганизации и фермерские хозяйства. С экономической точки зрения концентрация производства в крупных товарных хозяйствах не только резко снижает издержки, но и дает возможность доступа в торговые сети, что стабилизирует цены на овощную продукцию.

В решении проблемы подъема овощеводческой отрасли значительная роль отводится сорту, как основному элементу современных технологий возделывания овощных культур, поэтому спрос на новые сорта и гибриды постоянно растет. В настоящее время для потребителя предлагается широкий ассортимент сортов столовых корнеплодов Российской и иностранной селекции, однако среди производителей, предпочтение отдается гибридам $\mathrm{F}_{1}$, которые по сравнению с сортами-популяциями наиболее выровнены, пластичны и как следствие технологичны. В связи с возросшим спросом их число по группе корнеплодных культур значительно увеличилось за последнее двадцатилетие (рис. 6). В 2020 году в государственном реестре селекционных достижений, допущенных к использованию в РФ, зарегистрировано по моркови столовой 165 гибридов $F_{1}$ или 50,5\% от общего количества, по свекле - 29 или $18 \%$, по редису - 47 или
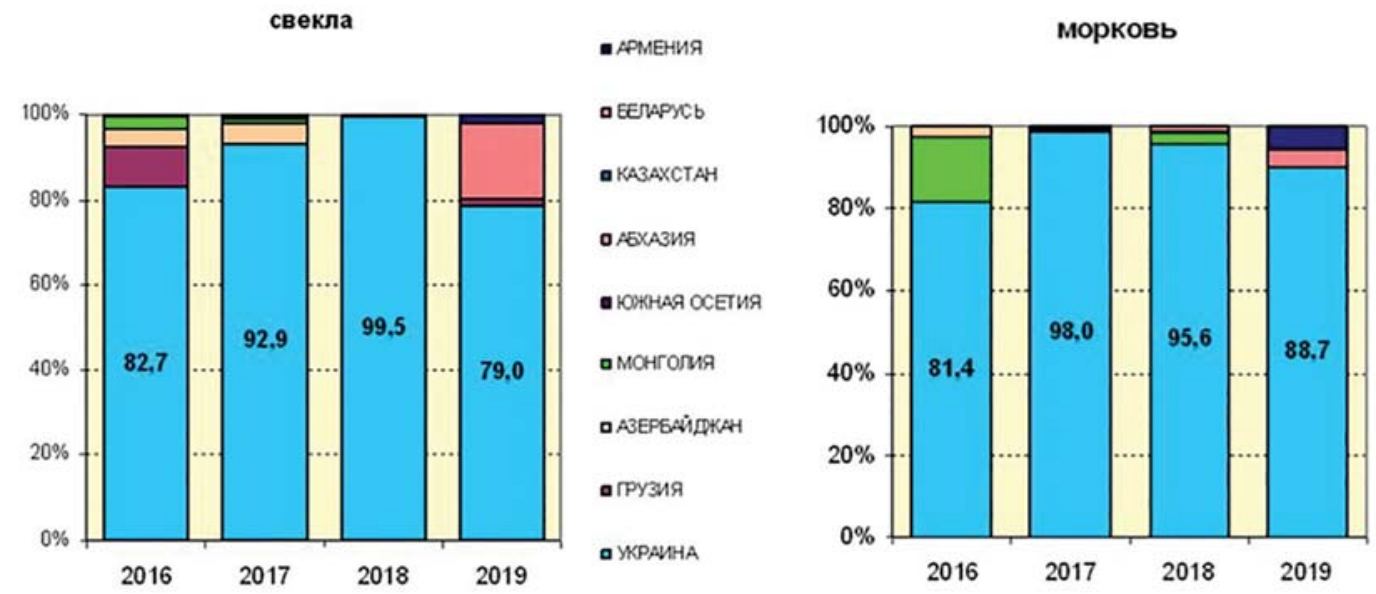

Рис. 5. Структура экспорта товарной продукции моркови и свеклы столовой, производимой в РФ (2016-2019гг.) Fig. 5. Export structure of commercial products of carrots and beets produced in the Russian Federation (2016-2019)

полной мере обеспечено корнеплодами, в частности морковью и свеклой столовой. Несмотря на это, часть товарной продукции экспортируется в другие страны (рис.3). В 2019 году отмечено увеличение объема экспортной продукции моркови, свеклы, репы и прочих съедобных корнеплодов, по сравнению с тремя предшествующими годами. Основная доля продукции экспортируется на Украину (7999\%), а также в Беларусь, Монголию, Казахстан (рис.5).

Следует отметить, что доля экспорта невелика и составляет по моркови столовой 1,8-2,3\% от общего объема производимой продукции в промышленном секторе, по свекле - 1,5-1,6\%, однако распределение этого количества продукции на внутреннем рынке страны способствовало бы сокращению разницы между фактическим потреблением и рекомендованным нормам.

\section{Возможные пути увеличения производства}

Наращивание товарного производства этих культур в целом по стране осуществимо при взаимодействии двух основных факторов: увеличения урожайности за счет внедрения новых гибридов $\mathrm{F}_{1}$ и сортов со стабильно высокой урожайностью, оптимизации питания растений, с учетом почвенно-климатических условий и специфики возделываемых культур, и роста посевных площадей [5].

Производство в хозяйствах населения имеет тенденцию к сокращению, и в связи с этим основная нагрузка

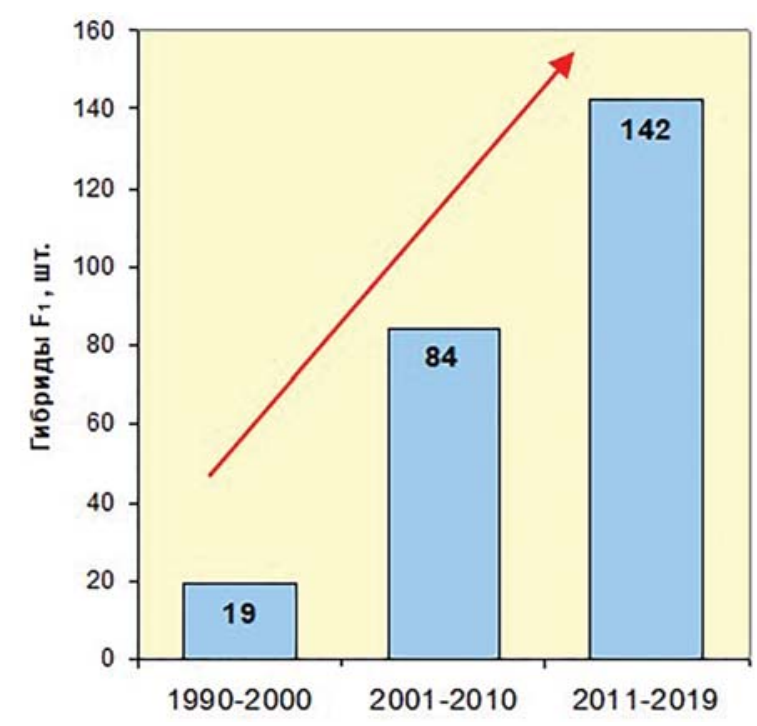

Рис. 6. Число гибридов в группе столовых корнеплодов, зарегистрированных в “Государственном реестре селекционных достижений” в разные временные периоды

दig. 6. The number of hybrids in the group of table root crops registered in the "State register of breeding achievements" in different time periods 
19\%, по редьке европейской - 1 или 3,2\%. При этом, большинство предлагаемых гибридов $F_{1}$ иностранной селекции. В настоящее время в севооборотах хозяйств сорта и гибриды $F_{1}$ российской селекции практически отсутствуют, за исключением некоторых сортов широкого ареала распространения. Сегодня при создании конкурентоспособных гибридов $\mathrm{F}_{1}$ необходимо вести «диалог» напрямую с производителями, учитывать их мнение к комплексу признаков, для понимания «модели» создаваемых селекционных достижений: высокая и стабильная урожайность, товарность, привлекательный внешний вид корнеплода, устойчивость к болезням и вредителям, качество продукции и пригодность к механизированному возделыванию и переработке. Ряд производителей готовы предоставить свои площади как для испытания, так и для увеличения объемов производства продукции с условием, что они дадут гарантированный урожай высокого качества $[1,9,11]$.

\section{Направления и методы селекции}

В России очень небольшое число оригинаторов занимаются гетерозисной селекцией столовых корнеплодов. В связи с этим, в рамках программы импортозамещения перед «Федеральным научным центром овощеводства», как одним из главных селекционных учреждений нашей страны, стоит задача создания конкурентоспособных гибридов моркови и свеклы столовой, редиса, и привлечения к ним внимания товаропроизводителей.

Коллективом лаборатории селекции и семеноводства столовых корнеплодов совместно с лабораториями биотехнологии, иммунитета и защиты растений, генетики и цитологии, лабораторно-аналитическим центром ФГБНУ ФНЦО, проводится большая работа по созданию сортовпопуляций и гетерозисных гибридов, отвечающих современным требованиям, с использованием классических и современных методов, способствующих ускорению селекционного процесса (рис. 7) [2, 8, 13, 16].

Определяющим фактором, влияющим на эффект гетерозиса, является разработка принципов подбора пар для скрещивания, включая использование полиплоидных форм, биотипов с ЦМС, самонесовместимых линий. Для получения межлинейных гибридов, необходимо создать фонд инбредных линий, полученных из перспективных сортовых и гибридных популяций, характеризующихся высокой комбинационной способностью по комплексу хозяйственно значимых признаков. Создание таких линий - это трудоемкий и длительный процесс, который занимает около 10-14 лет в зависимости от биологических особенностей культуры. Значительно ускорить данный этап работы удается при использовании технологии получения удвоенных гаплоидов (DH - технологии). Гаплоидные технологии расширяют спектр формообразовательного процесса, облегчают отбор полезных генов, способствуют обнаружению редких рецессивных аллелей, помогают создать уникальные формы, таким образом, повышают эффективность практической селекции [17]. В связи с тем, что на эффективность данной технологии влияет большое количество факторов (условия выращивания донорных растений, генотип, стадия развития микроспор, предобработка бутонов, питательные среды и условия культивирования), существует необходимость разработки элементов методики для конкретного генотипа.

Работа в этом направлении успешно ведется по моркови столовой. Усовершенствована технология получения удвоенных гаплоидов в культуре микроспор. В культуре неопыленных семяпочек оптимизирована технология для различных слабоотзывчивых сортообразцов и селекционных ценных форм [16]. В ФГБНУ ФНЦО впервые удалось осуществить полный цикл получения $\mathrm{DH}$-растений редиса европейского в культуре микроспор in vitro, до включения материала в селекционный процесс [7].

Ускорить процесс получения линейного материала на 34 года также удается путем включения в классическую селекцию отдельных технологических элементов: культура штеклингов, защищенный грунт, климокамеры, малообъемная технология, яровизация на ранней стадии развития. Важнейшим вопросом при создании линий является их поддержание и размножение, поскольку последовательное самоопыление снижает фертильность пыльцевых зерен и в сочетании с самонесовместимостью приводит к снижению семенной продуктивности индивидуальных растений. Для решения этой проблемы, начиная с 4-5 инцухта, целесообразно проводить чередование сестринских скрещиваний и инбридинга, что способствует преодолению инбредной депрессии [14].

Сегодня много говорится о пользе потребления свежих овощей с целью профилактики заболеваний и здорового образа жизни человека. Но не стоит забывать о том, что при недобросовестном и неконтролируемом выращивании овощей с применением большого количества химикатов, в организм человека вместе с полезными веществами поступают нитраты и пестициды, которые негативно влияют на продолжительность жизни, провоцируют болезни эндокринной системы, легких, сердца, снижают иммунитет и т.д. Выращивание столовых корнеплодов и получение достойных урожаев возможно при минимальной пестицидной нагрузке, при условии возделывания устойчивых сортов и гибридов к болезням вегетации и хранения. В связи с этим, одним из важных элементов селекционного процесса при получении сортов-популяций и гетерозисных гибридов в ФГБНУ ФНЦО, является многократная оценка разнообразного селекционного материала, и поиск источников со стабильной устойчивостью к патогенам различной этиологии, в сочетании с требуемым комплексом хозяйственно ценных признаков [6].

С применением представленной схемы селекционного процесса (рис.7) создан богатейший линейный материал для селекции новых сортов и гетерозисных гибридов. По моркови столовой получены изогенные пары (мужская стерильная линия - закрепитель стерильности) на основе сортопопуляций Минор и Марлинка и материала иностранной селекции. По свекле столовой, с применением методов гаметной селекции, на основе сортопопуляции Нежность, созданы линии со 100\% проявлением мужской стерильности и потенциальные закрепители, характеризующиеся $100 \%$ фертильностью и стабильно закрепляющие ЦМС в течение нескольких лет. По редису на основе гибридных и инбредных потомств сортопопуляции Моховский и других сортов выделены линии со 100\%-ной $\mathrm{ms}$, в которых методом мультиплексной ПЦР подтверждено наличие цитоплазмы Ogura, полностью фертильные закрепители [15]. По перечисленным культурам, на основе популяций различного происхождения, также получено большое число фертильных линий-опылителей с комплексом необходимых признаков.

\section{Селекционные достижения}

последних лет ФГБНу ФНЦО

Созданные селекционерами ФГБНУ ФНЦО сорта и гибриды $\mathrm{F}_{1}$ показывают хорошие результаты в высокотоварных хозяйствах, применяющих промышленные технологии: сеялки точного высева, полный набор пестицидов для защиты растений, механизированную уборку и предпродажную подготовку. Так, например, у гибридов $F_{1}$ моркови Надежда (сортотип Нантский) и Риф (сортотип Шантенэ) урожайность в ООО «Озера» достигает 90 т/га при товарности 85-90\%. Эти гибриды отличаются повы- 


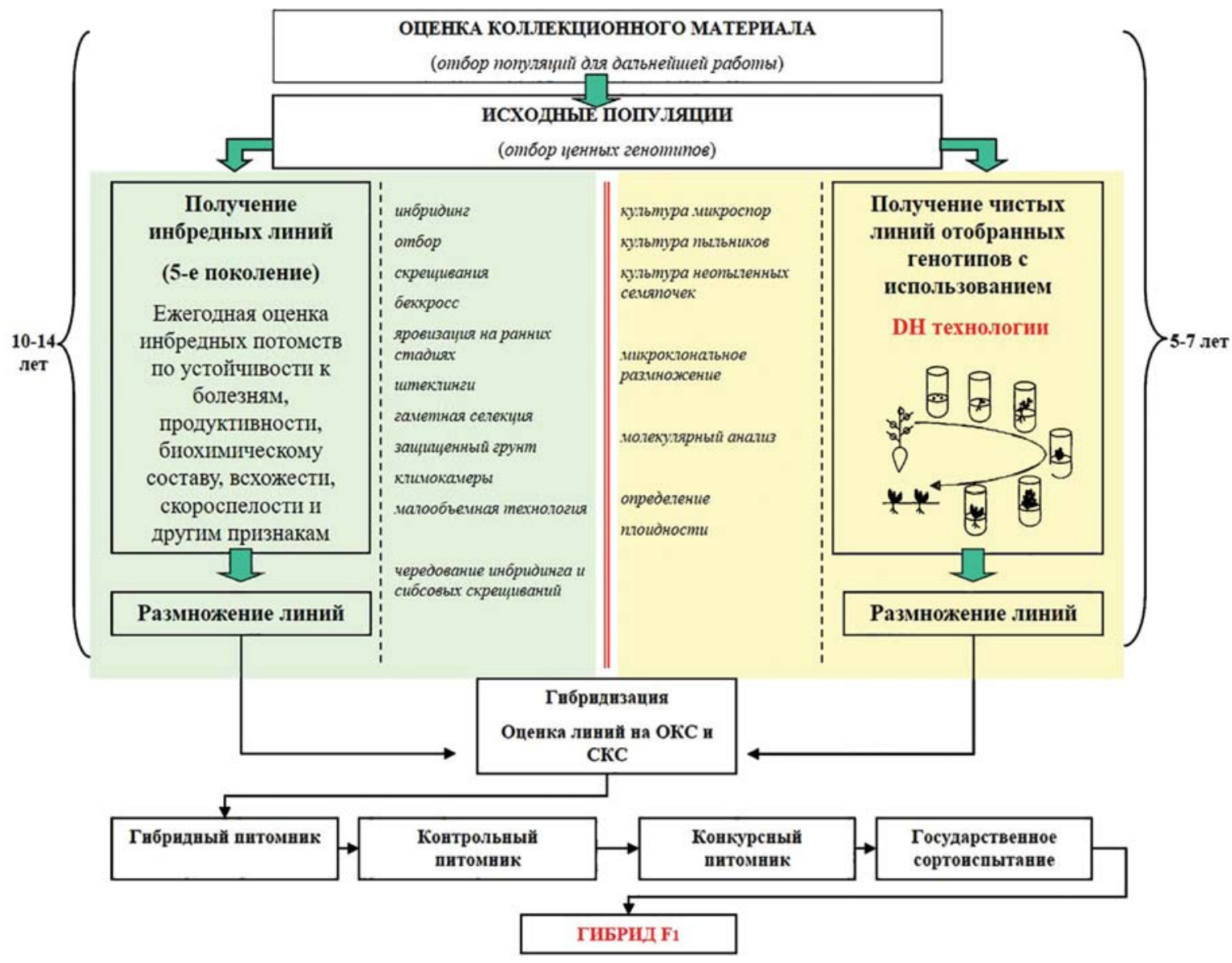

Рис.7. Селекционная схема создания гетерозисных гибридов столовых корнеплодов с применением методов классической селекции и DH-технологии

Fig.7. The selection scheme for the creation of F1 hybrids of table root crops using classical selection methods and DH technology

шенным содержанием каротина, пригодностью к длительному хранению с сохранностью 90-95\%, устойчивостью к болезням. Сорт моркови Маргоша на основании экологического испытания позволяет расширить ареал его районирования, при этом сохраняя урожайность и устойчивость к болезням на высоком уровне.

Созданные в лаборатории селекции и семеноводства столовых корнеплодов одно-двусемянные сорта свеклы столовой Любава и Гаспадыня и раздельноплодные Бордо односемянная и Добрыня, позволяют без прореживания формировать оптимальную густоту стояния, благодаря которой достигается высокий уровень урожайности (60-70 т/га), товарности (95-98\%) и высокое качество продукции корнеплодов.

На салатных линиях - нового уровня промышленной технологии с контролируемым микроклиматом и питанием хорошо показывают себя японская репа сортов Гейша, Снегурочка с салатными листьями и нежной сочной мякотью корнеплода, ультраскороспелые листовые формы Сапфир, Селекта и Бирюза с неопушенной высоковитаминной зеленью, устойчивые к пониженной освещенности в осенне-зимний период.

Особо выделяются сорта редиса, выведенные в последнее время, скороспелые с вегетационным периодом 20-25 суток, устойчивые к стеблеванию и бактериальным болезням: Ария (сортотип Французский завтрак) с корнеплодом удлиненно-цилиндрической формы, пригодный к уплотненной схеме посева (4 X 5см); высокоурожайный теневыносливый сорт Соната с округлым красным корнеплодом; темно-фиолетовый сорт Мавр и аналог Розово-красного с белым кончиком - Миф, отличаются высоким содержанием аскорбиновой кислоты (до 33 мг\%).

\section{Заключение}

В условиях, вводимых с 2014 года санкций, за последние годы отмечено незначительное снижение импорта овощной продукции и рост урожайности овощных культур, что с одной стороны может привести к инвестиционной привлекательности овощеводства, а с другой - к снижению конкуренции на внутреннем рынке и, как следствие, увеличению роста цен на продовольствие. Сложившаяся ситуация противоречит «Доктрине о продовольственной безопасности», утвержденной указом президента РФ от 21 января 2020 года, в которой говориться о том, что пищевая продукция должна соответствовать обязательным требованиям и быть экономически доступной для каждого гражданина нашей страны, в объемах, не меньше рациональных норм потребления. Для повышения уровня обеспеченности населения отечественной продукцией, пусть даже не до нормативных показателей, необходимо, на государственном уровне, разработать и осуществить общероссийскую схему размещения и развития овощеводства, усовершенствовать организационно-экономический механизм улучшения использования биоклиматического потенциала овощеводческих зон, осуществить регулирование межрегионального обмена овощной продукцией [12].

Очевидной причиной, задерживающей инновационное развитие отрасли овощеводства России, является зависимость хозяйств от сортов и гибридов зарубежной селекции. Одним из путей повышения продовольственной безопасности в условиях постоянно нарастающих санкций и увеличения производства овощных корнеплодов до уровня полного удовлетворения в них 
потребностей населения Российской Федерации, а также перспективы экспорта излишков может стать увеличение сегмента отечественных сортов и гибридов $F_{1}$.

Сорта и гибриды, полученные в ФГБНУ ФНЦО (ВНИИССОК), характеризуются комплексом признаков, позволяющих получать стабильный урожай, превосходят иностранные гибриды по биохимическим показателям, обладают высокой сохранностью при длительном хранении, пригодны для промышленных технологий. Все

\section{Об авторах:}

Ветрова Светлана Александровна - кандидат с.-х. наук, старший научный сотрудник лаборатории селекции и семеноводства столовых корнеплодов, http://orcid.org/0000-0002-9897-0413

Вюртц Татьяна Сергеевна - кандидат с.-х. наук, научный сотрудник лаборатории репродуктивной биотехнологии в селекции сельскохозяйственных растений, http://orcid.org/0000-0003-3956-4172

Заячковская Татьяна Владимировна - кандидат с.-х. наук, старший научный сотрудник лаборатории селекции и семеноводства столовых корнеплодов, http://orcid.org/0000-0001-8435-8197

Степанов Виктор Алексеевич - кандидат с.-х. наук, ведущий научный сотрудник, зав. лаборатории селекции и семеноводства столовых корнеплодов, http://orcid.org/0000-0002-8749-1425

\section{- Литература}

1. Ветрова С.А., Заячковский В.А., Мухина К.С. Раздельноплодные сорта свеклы столовой селекции ФГБНУ ФНЦО в разрезе современных требований сельхозпроизводителей. Аграрная наука. 2019;(11-12):61-67. https://doi.org/10.32634/0869-8155-2019-333-10-61-67

2. Ветрова С.А., Фёдорова М.И., Козарь Е.Г. Инбредные потомства штеклингов - источник отбора мужски стерильных форм свеклы столовой. Наука, инновации и международное сотрудничество молодых ученых-аграриев. ФГБНУ ВНИИЗБК. 2016. С. 57-62.

3. Государственный реестр селекционных достижений, допущенных к использованию. http://gossortrf.ru/gosreestr.html

4. Доктрина продовольственной безопасности Российской Федерации Москва. 2020. http://kremlin.ru/acts/news/62627

5. Елькина Г.Я. Оптимизация минерального питания растений на подзолистых почвах. Вестник института биологии Коми научного центра Уральского отделения РАН. 2011;(12):42-45

6. Енгалычева И.А., Козарь Е.Г. Основные направления исследований вирусных болезней овощных культур в ФГБНУ ФНЦО (мониторинг, иммунитет источники устойчивости). Аграрная наука. 2019; № S3: 79-85. DOI 10.32634/0869-8155-2019-326-3-79-85

7. Козарь Е.В., Домблидес Е.А., Солдатенко А.В. Факторы, влияющие на получение $\mathrm{DH}$-растений в культуре микроспор in vitro редиса европейского. Вавиловский журнал генетики и селекции. 2020;24(1):31-39. DOI 10.18699/VJ20.592

8. Козарь Е.Г., Федорова М.И., Ветрова С.А., Заячковский В.А., Степанов В.А. Оценка функциональных параметров микрогаметофита инбредных растений свеклы столовой (методические рекомендации). Москва: 000 «Полиграф плюс». 2017; 34 с

9. Леунов В.И. Направления в селекции и семеноводстве овощных корнеплодных культур. Картофель и овощи. 2017;(10):6-9.

10. Разин А.Ф., Шатилов М.В., Мещерякова Р.А., Сурихина Т.Н., Разин О.А Телегина Г.А. Овощи борщевой группы в России. Картофель и овощи. 2019;(10):10-13. DOI: 10.25630/PAV.2019.37.28.009

11. Романов Т.С. Первые шаги реального партнерства. Картофель и овощи. 2019:(10):6-7.

12. Солдатенко А.В., Разин А.Ф., Шатилов М.В., Иванова М.И., Разин О.А Россинская О.В., Башкиров О.В. Межрегиональный обмен в контексте выравнивания потребления овощей в субъектах федерации. Овощи России 2018;(6):41-46. https://doi.org/10.18619/2072-9146-2018-6-41-46

13. Степанов В.А., Федорова М.И., Ветрова С.А., Заячковский В.А. Заячковская Т.В., Вюртц Т.С. Новый сортимент для селекции овощных корнеплодов и технологии его поддержания. Овощи России. 2018;(2):28-31 https://doi.org/10.18619/2072-9146-2018-2-28-31

14. Федорова М.И., Козарь Е.Г., Ветрова С.А., Заячковский В.А., Степанов В.А. Факторы, влияющие на репродуктивную способность инбредных растений свеклы столовой при создании линейного материала для селекции // Вавиловский журнал генетики и селекции. - 2019;23(4):439-447. DOI 10.18699/VJ19.512

15. Domblides E.A., Domblides A.S., Zayachkovskaya T.V., Bondareva L.L. Identification of cytoplasm types in accessions of the brassicaceae family (brassicaceae burnett) by dna markers. Russian Journal of Genetics: Applied Research 2016. T. 6. № 5. C. 510-519.

16. Domblides E.A., Shmykova N.A., Shumilina D.V., Zayachkovskaya T.V., Vjurtts T.S. Kozar E.V., Kan L.Yu, Romanov V.S., Domblides A.S., Pivovarov V.F. Soldatenko A.V. Biotechnological approaches for breeding programs in vegetable crops. Agrosym 2017 book of proceedings. 2017. C. 452-460.

17. Forster B. P., Heberle-Bors E., Kasha K. J., Touraev A. The resurgence of haploids in higher plants. Trends Plant Sci. 2007;12(8):368-375.

18. http://www.fao.org/faostat/ru

19. https://www.gks.ru

20. https://agrovesti.net

21. http://customs.ru это определяет их конкурентоспособность и в рамках программы импортозамещения позволяет использовать продукцию отечественных оригинаторов в севооборотах хозяйств без риска для их прибыли. В связи с этим развитие производства сельскохозяйственной продукции, в том числе и отрасли овощеводства, может набрать темпы развития особенно при условии государственной поддержки отечественных оригинаторов, что в свою очередь сделает эту отрасль инвестиционно привлекательной.

\section{About the authors:}

Svetlana A. Vetrova. - Cand. Sci. (Agriculture), senior researcher of the laboratory of breeding and seed production of table root crops;

Tatiana S. Vjurtts - Cand. Sci. (Agriculture),

researcher of laboratory of reproductive

biotechnology in crop breeding;

Tatiana V. Zayachkovskaya - Cand. Sci. (Agriculture),

senior researcher of the laboratory of breeding

and seed production of table root crops

Victor A. Stepanov - Cand. Sci. (Agriculture),

leading researcher of the laboratory of breeding and seed production of table root crops.

\section{- References}

1. Vetrova S.A., Zayachkovskyi V.A., Muhina K.S. Monogermity varieties of beetroot in the context of modern requirements of agricultural producers. Agrarian science. 2019;(11-12):61-67. (In Russ.) https://doi.org/10.32634/0869-8155-2019-333-10-61-67

2. Vetrova S. A., Fedorova M. I., Kozar E. G. Inbred offspring of shtekling - a source of selection of male sterile forms of table beet. Science, innovation and international cooperation of young agricultural scientists. GNU VNIIZBK. 2016 Pp. 57-62. (In Russ.)

3. State register of selection achievements approved for use. http://gos sortrf.ru/gosreestr.html (In Russ.)

4. The doctrine of food security of the Russian Federation. Moscow. 2020. http://kremlin.ru/acts/news/62627 (In Russ.)

5. Elkina G.Ya. Optimization of mineral nutrition of plants on podzolic soils Bulletin of the Institute of biology, Komi scientific center, Ural branch of RAN. 2011:(12):42-45. (In Russ.)

6. Engalycheva I. A., Kozar E. G. The Main directions of research of viral diseases of vegetable crops in the Federal state budgetary institution (monitoring, immunity, sources of resistance). Agrarian science. 2019; S3: 79-85. (In Russ.) DOI: 10.32634/0869-8155-2019-326-3-79-85

7. Kozar E.V. Domblides E.A., Soldatenko A.V. Factors affecting $\mathrm{DH}$ plants in vitro production from microspores of European radish. Vavilov Journal of Genetics and Breeding. 2020; 24(1):31-39. (In Russ.) DOI 10.18699/VJ20.592

8. Kozar E.G., Fedorova M.I., Vetrova S.A., Zayachkovskyi V.A., Stepanov V.A Estimation of functional parameters of microgametophyte of inbred beetroot plants (methodological recommendations). Moscow: 000 "Polygraph plus". 2017. 34 p. (In Russ.)

9. Leunov V.I. Directions in selection and seed production of vegetable root crops. Potatoes and vegetables. 2017:(10):6 -9. (In Russ.)

10. Razin A.F., Shatilov M.V., Meshcheryakova R.A., Surikhina T.N., Razin O.A., Telegina G.A. Borscht vegetables in Russia. Potatoes and vegetables. 2019;(10):10-13. (In Russ.) DOI: 10.25630/PAV.2019.37.28.009

11. Romanov T.S. The First steps of real partnership. Potatoes and vegetables. 2019;(10): 6-7. (In Russ.)

12. Soldatenko A.V., Razin A.F., Shatilov M.V., Ivanova M.I., Razin O.A Rossinskaya O.V., Bashkirov O.V. Interregional exchange in the context of the alignment of the consumption of vegetables in subjects of the Russian Federation. Vegetable crops of Russia. 2018;(6):41-46. (In Russ.) https://doi.org/10.18619/2072-9146-2018-6-41-46

13. Stepanov V.A., Fedorova M.I., Vetrova S.A., Zayachkovskyi V.A., Zayachkovskaya T.V., Vjurtts T.S. A new assortment for the selection of root vegetable, and technology maintenance. Vegetable crops of Russia. 2018;(2):28-31 (In Russ.) https://doi.org/10.18619/2072-9146-2018-2-28-31

14. Fedorova M.I. Kozar E.G., Vetrova S.A. Zayachkovskyi V.A., Stepanov V.A. Factors to affect inbred beet plants while developing material for linear selection. Vavilov Journal of Genetics and Breeding. 2019; 23(4): 439-447. (In Russ.) DOI 10.18699/VJ19.512

15. Domblides E.A., Domblides A.S., Zayachkovskaya T.V., Bondareva L.L. Identification of cytoplasm types in accessions of the brassicaceae family (brassicaceae burnett) by dna markers. Russian Journal of Genetics: Applied Research. 2016. T. 6. № 5. C. 510-519.

16. Domblides E.A., Shmykova N.A., Shumilina D.V., Zayachkovskaya T.V. Vjurtts T.S., Kozar E.V., Kan L.Yu., Romanov V S., Domblides A.S., Pivovarov V.F., Soldatenko A.V. Biotechnological approaches for breeding programs in vegetable crops. Agrosym 2017 book of proceedings. 2017. C. 452-460.

17. Forster B.P., Heberle-Bors E., Kasha K.J., Touraev A. The resurgence of haploids in higher plants// Trends Plant Sci. 2007;12(8):368-375.

18. http://www.fao.org/faostat/ru

19. https://www.gks.ru

20. https://agrovesti.ne

21. http://customs.ru 